Tropical Journal of Pharmaceutical Research April 2018; 17 (4): 653-659

ISSN: $1596-5996$ (print); 1596-9827 (electronic)

(C) Pharmacotherapy Group, Faculty of Pharmacy, University of Benin, Benin City, 300001 Nigeria.

\title{
Effect of Bushen yixue decoction on follicular development in experimental androgen-sterilized anovulatory rats and its possible mechanism of action
}

\author{
Hai-Ning Liu ${ }^{1-5}$, Xiu-Ming Tang ${ }^{6}$, Hai-Jun Qu ${ }^{7}$, Xiao-Jing Guo ${ }^{6}$, Zi-Jiang Chen ${ }^{1,3-}$ \\ $5,8,9$ \\ ${ }^{1}$ Center for Reproductive Medicine, Shandong Provincial Hospital Affiliated to Shandong University, Jinan 250021, ${ }^{2}$ Center for \\ Reproductive Medicine, Qingdao Municipal Hospital, Qingdao 266011, ${ }^{3}$ National Research Center for Assisted Reproductive \\ Technology and Reproductive Genetics, ${ }^{4}$ The Key laboratory for Reproductive Endocrinology of Ministry of Education, \\ ${ }^{5}$ Shandong Provincial Key Laboratory of Reproductive Medicine, Jinan 250021, ${ }^{6}$ Department of Reproductive Medicine, The \\ Affiliated Hospital of Qingdao University, ${ }^{7}$ Department of Pharmacy, The Affiliated Hospital of Qingdao University, Qingdao \\ $266003,{ }^{8}$ Center for Reproductive Medicine, Ren Ji Hospital, School of Medicine, Shanghai Jiao Tong University, ${ }^{9}$ Shanghai \\ Key Laboratory for Assisted Reproduction and Reproductive Genetics, Shanghai 200127, PR China
}

*For correspondence: Email: chenzjhp@126.com; Tel: +86-531-85651190

Sent for review: 20 September 2017

Revised accepted: 16 March 2018

\begin{abstract}
Purpose: To explore the activities of Bushen yixue decoction (BSY) against follicular development in anovulatory rats.

Methods: Rats were divided into normal, normal control, clomifene citrate (positive control, orally, 5 $\mathrm{mg} / \mathrm{kg}$ ), and BSY (orally, 50, 100, $200 \mathrm{mg} / \mathrm{kg}$ ) groups. Anovulatory rats were prepared by testosterone propionate injection (1.5 mg/rat). After 70 days, daily vaginal smears were performed for 10 days until no obvious sexual cycle was observed, indicating that androgen-sterilized anovulatory rats were successfully established. High performance liquid chromatography (HPLC) was used to analyse BSY chemical composition. Levels of follicular stimulating hormone (FSH), luteinizing hormone (LH), oestradiol (E2), progesterone (P), prolactin (PRL), inhibin (INH), activin (ACT) and follistatin (FS) were determined by radioimmunoassay or enzyme linked immunosorbent assay (ELISA). Western blotting was used to determine Bcl-2, cleaved-caspase-3, Bax, MMP-9 and VEGF in ovarian tissues.

Results: BSY increased $(p<0.05)$ the levels of FSH, LH, E2 $(p<0.05)$ and ACT, but decreased $(p<$ $0.05)$ the levels of PRL, INH and FS, relative to control rats. Expressions of VEGF $(p<0.01), M M P-9(p$ $<0.05)$ and Bcl-2 $(p<0.01)$ were up-regulated by BSY, whereas Bax $(p<0.01)$ and $C$-caspase-3 $(p<$ $0.01)$ were down-regulated.

Conclusion: BSY promotes follicular development of anovulatory rats via regulating INH-ACT-FS hormones, VEGF, MMP-9, Caspase-3, Bax, and Bcl-2. Thus, BSY may have the potential to be developed for clinical management of infertility.
\end{abstract}

Keywords: Bushen yixue decoction, Follicular development, Inhibin-Activin-Follistatin (INH-ACT-FS) system, Androgen-sterilized anovulatory rats

This is an Open Access article that uses a funding model which does not charge readers or their institutions for access and distributed under the terms of the Creative Commons Attribution License (http://creativecommons.org/licenses/by/4.0) and the Budapest Open Access Initiative (http://www.budapestopenaccessinitiative.org/read), which permit unrestricted use, distribution, and reproduction in any medium, provided the original work is properly credited.

Tropical Journal of Pharmaceutical Research is indexed by Science Citation Index (SciSearch), Scopus, International Pharmaceutical Abstract, Chemical Abstracts, Embase, Index Copernicus, EBSCO, African Index Medicus, JournalSeek, Journal Citation Reports/Science Edition, Directory of Open Access Journals (DOAJ), African Journal Online, Bioline International, Open-J-Gate and Pharmacy Abstracts 


\section{INTRODUCTION}

Infertility is commonly defined as failure to conceive after 1 year of regular intercourse without contraception for women less than 35 years old, and half a year for women more than 35 years old. Nowadays, infertility has become a serious worldwide problem in reproductive health and causes psychological burdens both in individuals and couples [1-3]. Previous epidemiological studies reported that ovarian dysfunction can result in various problems, such as female endocrine disorders, continuous ovulation, less ovulation, inappropriate ovulation, polycystic ovary syndrome and hyperprolactinemia [4]. Importantly, it was shown that ovarian dysfunction is the most important cause of female infertility [2]. Normal follicular development is a pre-condition for ovulation and fertility. In recent years, researchers have found that follicular development in the normal menstrual cycle is closely associated with gonadotropins, such as follicular stimulating hormone $(\mathrm{FSH})$, luteinizing hormone (LH), oestradiol (E2), progesterone $(\mathrm{P})$, and prolactin (PRL), [5]. Follicular development is also closely related to the genes for angiogenesis, matrix metalloproteinases and apoptosis [6-9].

In Chinese medicinal theory, it is commonly hypothesized that infertility is mainly related to deficiencies of the kidney, and nourishing the kidney and blood is therefore the primary therapy for treating infertility [10-12]. Based on this strategy, Bushen yixue decoction (BSY) is an effective prescription commonly used to treat infertility in China. BSY is mainly composed of 10 traditional Chinese medicines (TCMs) (Table 1). However, knowledge of the chemical composition and pharmacological studies of BSY are incomplete. In this work, we determined the main chemical constituents of BSY and the activities of BSY on anovulatory rats induced by testosterone propionate.

Table 1: Composition of Bushen yixue decoction (BSY)

\begin{tabular}{|c|c|c|c|}
\hline $\begin{array}{l}\text { Plant } \\
\text { material }\end{array}$ & $\begin{array}{l}\text { Quantity } \\
\text { (g) }\end{array}$ & $\begin{array}{l}\text { Plant } \\
\text { material }\end{array}$ & $\begin{array}{l}\text { Quantity } \\
\text { (g) }\end{array}$ \\
\hline $\begin{array}{l}\text { Rhizoma } \\
\text { cyperi }\end{array}$ & 10 & $\begin{array}{l}\text { Folium } \\
\text { epimedii }\end{array}$ & 15 \\
\hline $\begin{array}{l}\text { Herba } \\
\text { leonuri }\end{array}$ & 10 & $\begin{array}{l}\text { Semen } \\
\text { cuscutae }\end{array}$ & 10 \\
\hline $\begin{array}{l}\text { Radix } \\
\text { achyranthes } \\
\text { Bidentata }\end{array}$ & 10 & $\begin{array}{l}\text { Radix } \\
\text { angelica } \\
\text { Sinensis }\end{array}$ & 8 \\
\hline $\begin{array}{l}\text { Caulis } \\
\text { spatholobi }\end{array}$ & 15 & Cornu cervi & 15 \\
\hline $\begin{array}{l}\text { Flos } \\
\text { carthami }\end{array}$ & 15 & $\begin{array}{l}\text { Herba } \\
\text { cistanches }\end{array}$ & 10 \\
\hline
\end{tabular}

\section{EXPERIMENTAL}

\section{Materials and reagents}

All crude TCMs were purchased from the TongRen-Tang Co., Ltd (Jinan, China). A series of voucher specimens (voucher no. 20140752014085) was stored in our laboratory for future reference. Radioimmunoassay kits for $\mathrm{FSH}$, $\mathrm{LH}$, oestradiol (E2), progesterone $(\mathrm{P})$, and prolactin $(P R L)$ were purchased from Beijing Huaying Biotechnology Institute (Beijing, China). ELISA kits for inhibin (INH), activin (ACT), and follistatin (FS) were obtained from K-X Biotechnology (Shanghai, China). Primary antibodies against $\mathrm{Bcl}-2$ and cleaved-caspase-3 (C-caspase-3) were purchased from Cell Signaling Technology (Beverly, MA, USA), and antibodies against Bax, MMP-9, VEGF, and $\beta$-actin and horseradish peroxidase (HPR) conjugated secondary antibodies were obtained from Abcam Biotechnology (Cambridge, MA, USA). Rutin, tiliroside, quercetin, kaempferide, safflomin $A$, hyperoside, and quercitrin were purchased from the National Institutes for Food and Drug Control (Beijing, China).

\section{Preparation of BSY}

The commonly used clinical prescription in China for BSY is composed of 10 TCMs (Table 1). All dried herbal medicines were mixed and decocted three times with boiling water (eight volumes of water each time; w/v) for $1 \mathrm{~h}$ and filtered. The filtrate was concentrated and dried under vacuum at $50^{\circ} \mathrm{C}$ to produce the dried BSY extracts. The yield of BSY extracts was 11.54 $\% \mathrm{w} / \mathrm{w}$.

\section{HPLC analysis of BSY}

BSY extracts were dissolved in methanol for HPLC assays. The analysis of chemical constituents in BSY extract was carried out on an Agilent Technologies 1200 system (Agilent, Santa Clara, CA, USA), and performed with a Diamonil $\mathrm{C}_{18}$ column $(4.6 \mathrm{~mm} \times 250 \mathrm{~mm}, 5 \mu \mathrm{m})$. The mobile phase was composed of acetonitrile (solvent A) and $0.3 \%$ phosphoric acid (solvent B): 0 - $25 \min (0-25 \%, A), 20-40 \min (25-40$ $\%$, A), $40-75 \min (40-80 \%, A), 75-85 \min$ $(80-100 \%$, A). The sample injection volume was $20 \mu \mathrm{L}$, testing time was $85 \mathrm{~min}$, and flow rate was $1 \mathrm{~mL} / \mathrm{min}$, column temperature was 30 ${ }^{\circ} \mathrm{C}$, and detection wavelength was $360 \mathrm{~nm}$.

\section{Animals}

All animal experiments were in accordance with the National Institute of Health Guide for the 
Care and Use of Laboratory Animals [13] and were approved by the Animal Care and Use Committee of the Center for Reproductive Medicine, Shandong Provincial Hospital Affiliated to Shandong University (no. 2014-S-1-5). Sprague Dawley (SD) female rats were obtained from the Shanghai Lab Animal Research Center (Shanghai, China).

\section{Determination of the acute toxicity of BSY}

The acute toxicity assays of BSY were carried out based on the method described in a previous report [14], with minor modifications. The rats were orally treated with a series of doses of BSY $(10,20,40,60,80,100,150,200,400$ and 600 $\mathrm{mg} / \mathrm{kg}$ ), and acute toxicity was observed within 7 days by calculating the $L_{50}$ value. The results indicated that there was no obvious acute toxicity in rats treated with $600 \mathrm{mg} / \mathrm{kg}$ of BSY.

\section{Animal model, grouping, and drug administration}

In total, 60 rats were divided into six groups: normal group, control group, clomifene citrate group (positive group) and three BSY (50, 100 and $200 \mathrm{mg} / \mathrm{kg} \mathrm{BSY}$ ) groups ( $\mathrm{n}=10$ per group). Anovulatory rats were prepared by subcutaneous injection of testosterone propionate $(1.5 \mathrm{mg} / \mathrm{rat}$, $0.05 \mathrm{~mL} / \mathrm{rat}$ ) into the back of the neck of female SD rats (9-days-old). In addition, normal rats were injected with the same amount of distilled water. After 70 days, daily vaginal smears were performed, and no obvious sexual cycle was observed, which meant the androgen-sterilized anovulatory rat procedure was successfully established [15]. Then, the normal and control rats were orally treated distilled water $(12 \mathrm{~mL} / \mathrm{kg})$, clomifene citrate $(5 \mathrm{~mL} / \mathrm{kg}$ ) was treated orally for 5 days, and BSY (50, 100, and $200 \mathrm{mg} / \mathrm{kg}$ ) was administered orally for 21 days.

\section{Sample collection}

The rats were weighed, anesthetised, and dissected from the abdomen, and then blood samples were collected and centrifuged at 3000 rpm for $10 \mathrm{~min}$ to separate serum samples, which were freeze-dried immediately, and stored at $-70{ }^{\circ} \mathrm{C}$ until analysis. After the aortic blood samples were collected, the rats were sacrificed using decollation, and the uterus and bilateral ovaries were collected and immediately weighed.

\section{Determination of serum hormone levels}

The serum levels of FSH, LH, E2, P, and PRL were analysed by commercial radioimmunoassay kits according to the manufacturer's instructions. All assays were repeated at least three times.

\section{Determination of INH, ACT and FS}

The ovary tissues were homogenized and centrifuged at $3000 \mathrm{rpm}$ for $10 \mathrm{~min}$. Subsequently, the supernatants were used for determining the levels of $\mathrm{INH}, \mathrm{ACT}$, and FS using commercial ELISA kits, following the manufacturer's instructions.

\section{Western blotting assay}

The ovary tissues were homogenized using a handheld tissue grinder, and the total proteins were collected. After determination of the protein concentration by a Bradford staining method, 30 $\mu \mathrm{g}$ of denatured protein were separated by sodium dodecyl sulphate/polyacrylamide gel electrophoresis, and subsequently transferred onto polyvinylidene difluoride membranes, which were blocked with $5 \%$ skim milk.

Subsequently, the transferred protein bands were probed with primary antibodies against Bcl2, Bax, C-caspase-3, MMP-9, VEGF and $\beta$-actin $(1: 2000)$ overnight, and subsequently probed with HPR-conjugated secondary antibody. Finally, the protein bands were detected by chemiluminescence using a ChemiDoc XRS imaging system (Bio-Rad Laboratories, Hercules, CA, USA). To equalize the protein loading, antibodies directed against $\beta$-actin were used.

\section{Statistical analysis}

All data are presented as the mean \pm SD. Oneway analysis of variance (ANOVA) was used to analyse the differences between two groups using SPSS, version 17.0 software (SPSS, Chicago, IL, USA). When $p<0.05$, the difference between two groups was recognized as statistically significant.

\section{RESULTS}

\section{Main chemical components of BSY}

Seven constituents, which included rutin, tiliroside, quercetin, kaempferide, safflomin A, hyperoside, and quercitrin were identified from BSY by using HPLC assays with reference compounds (Figure 1). The results indicated that flavone was one of the main active components of BSY. 


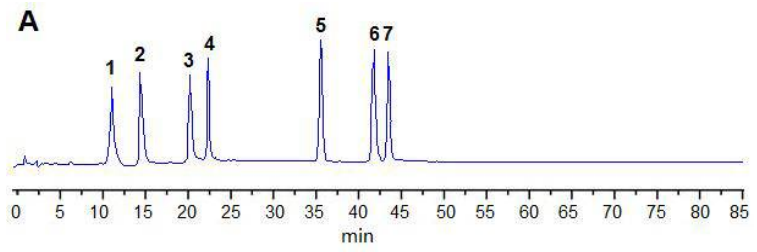

B

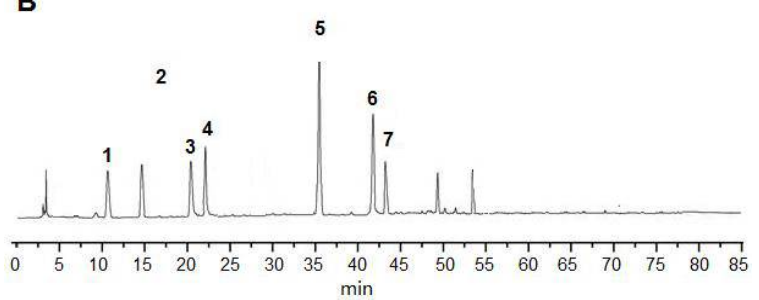

Figure 1: Main chemical components of BSY. (A): HPLC chromatograms of 7 standard compounds; (B): HPLC chromatogram of BSY sample. Peak 1: safflomin A, 2: tiliroside, 3: hyperoside, 4: rutin, 5: quercitrin, 6: quercetin and 7: kaempferide

\section{Effect of BSY on ovary and uterus indices of anovulatory rats}

After administration of testosterone propionate, the ovary and uterus indices of the rats were decreased $(p<0.01)$ (Figure 2). Within the positive group (clomifene citrate, $5 \mathrm{~mL} / \mathrm{kg}$ ), both the ovary and uterus indices of rats in the BSY treatment groups were significantly increased in a dose-dependent manner at doses of 100 and $200 \mathrm{mg} / \mathrm{kg}(p<0.01)$ when compared with the control rats.

\section{Effect of BSY on FSH, LH, E2, P, and PRL in the serum of anovulatory rats}

Compared with the normal rats, the contents of $\mathrm{FSH}, \mathrm{LH}$, and E2 were decreased $(p<0.01)$ for the anovulatory rats, whereas the PRL level was increased $(p<0.01)$ (Table 2). After treatment with clomifene citrate, the contents of $\mathrm{FSH}, \mathrm{LH}$, and E2 were markedly increased $(p<0.01)$, while the levels of PRL were decreased $(p<$ 0.01 ). Similarly, for the rats treated with BSY at doses of 100 and $200 \mathrm{mg} / \mathrm{kg}$, the levels of FSH, $\mathrm{LH}$, and E2 were increased $(p<0.05)$, and the PRL levels in the serum were decreased $(p<$ $0.05)$. However, no obvious difference was found in the serum level of $\mathrm{P}(p>0.05)$ compared to control rats (Table 2).

\section{Effect of BSY on the INH-ACT-FS system of anovulatory rats}

The results of the present investigation showed that after injection of clomifene citrate (1.25 $\mathrm{mg} / \mathrm{rat})$, the levels of INH and FS decreased ( $p<$ 0.01 ) compared with the normal rats, whereas the levels of ACT in ovarian tissues increased $(p$ $<0.01$ ) vs. the control rats (Table 3). Interestingly, the results also demonstrated that BSY $(50,100$, and $200 \mathrm{mg} / \mathrm{kg})$ decreased the levels of FS $(p<0.01)$, whereas it increased the ACT $(p<0.01)$ compared with control rats. In addition, BSY at doses of 100 and $200 \mathrm{mg} / \mathrm{kg}$ also decreased the level of $\mathrm{INH}(p<0.05)$.
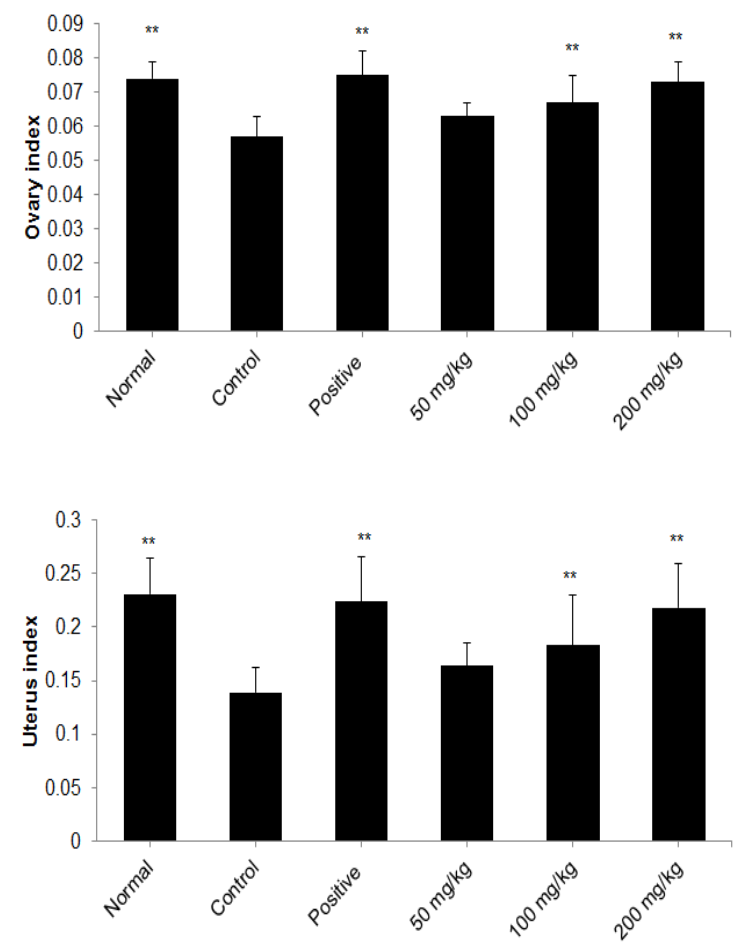

Figure 2: Effect of BSY on ovary and uterus index of anovulatory rats. Data were expressed as mean $\pm S D$, each group consisted of 10 rats $(n=10)$. All the drugs were treated orally; ${ }^{* *} p<0.01$, compared with the control rats

Table 2: Effect of BSY on the levels of FSH, LH, E2, P and PRL in anovulatory rats' serum

\begin{tabular}{|c|c|c|c|c|c|}
\hline Group & FSH (mIU/mL) & LH (mlU/mL) & E2 (pg/mL) & $P(\mathrm{ng} / \mathrm{mL})$ & PRL (ng/mL) \\
\hline Normal & $11.23 \pm 0.68^{\star \star}$ & $15.31 \pm 1.12^{\star \star}$ & $152.91 \pm 21.91^{\star \star}$ & $1.73 \pm 0.41$ & $16.24 \pm 1.37^{* \star}$ \\
\hline Control & $9.69 \pm 0.83$ & $12.14 \pm 1.05$ & $130.28 \pm 18.22$ & $1.65 \pm 0.51$ & $20.94 \pm 1.56$ \\
\hline Positive & $10.68 \pm 0.66^{*}$ & $14.59 \pm 1.25^{\star *}$ & $161.28 \pm 21.72^{\star *}$ & $1.58 \pm 0.44$ & $15.87 \pm 1.81^{* *}$ \\
\hline 50 mg/kg & $10.15 \pm 0.74$ & $14.51 \pm 1.34^{\star *}$ & $143.55 \pm 14.52^{*}$ & $1.43 \pm 0.49$ & $18.43 \pm 1.33$ \\
\hline 100 mg/kg & $10.52 \pm 0.55^{*}$ & $14.93 \pm 1.32^{\star *}$ & $154.52 \pm 15.71^{*}$ & $1.52 \pm 0.43$ & $17.71 \pm 1.02^{*}$ \\
\hline $200 \mathrm{mg} / \mathrm{kg}$ & $10.79 \pm 0.54^{*}$ & $14.72 \pm 1.47^{* *}$ & $162.95 \pm 11.74^{* *}$ & $1.46 \pm 0.51$ & $17.43 \pm 1.15^{\star}$ \\
\hline
\end{tabular}
with the control group 
Table 3: Effect of BSY on the INH, ACT and FS in ovarian tissue of anovulatory rats

\begin{tabular}{|c|c|c|c|}
\hline Group & INH (mIU/mL) & ACT (mIU/mL) & $\mathrm{FS}(\mathrm{pg} / \mathrm{mL})$ \\
\hline Normal & $115.02 \pm 7.02^{* *}$ & $88.03 \pm 19.91^{* *}$ & $0.59 \pm 0.04^{* *}$ \\
\hline $\begin{array}{l}\text { Control } \\
\text { Positive } \\
50 \mathrm{mg} / \mathrm{kg}\end{array}$ & $\begin{array}{l}133.67 \pm 8.93 \\
118.07 \pm 6.01^{* *} \\
131.03 \pm 7.81\end{array}$ & $\begin{array}{l}55.01 \pm 16.74 \\
87.96 \pm 21.32^{\star *} \\
77.16 \pm 8.98^{* *}\end{array}$ & $\begin{array}{l}1.32 \pm 0.22 \\
0.39 \pm 0.10^{\star *} \\
0.81 \pm 0.09^{* *}\end{array}$ \\
\hline $100 \mathrm{mg} / \mathrm{kg}$ & $121.38 \pm 6.74^{*}$ & $96.44 \pm 15.79^{* *}$ & $0.61 \pm 0.14^{* *}$ \\
\hline $200 \mathrm{mg} / \mathrm{kg}$ & $119.04 \pm 8.19^{*}$ & $103.61 \pm 19.95^{\star \star}$ & $0.49 \pm 0.12^{* *}$ \\
\hline
\end{tabular}

Data are expressed as mean $\pm S D$, each group consisted of 10 rats $(n=10)$. All the drugs were treated orally; ${ }^{*} p$ $<0.05,{ }^{* *} p<0.01$, compared with control group

Effect of BSY on Bcl-2, Bax, C-caspase-3, MMP-9, and VEGF of anovulatory rats

The results showed that protein expressions of $\mathrm{Bcl}-2$, MMP and VEGF in ovarian tissues of anovulatory rats were significantly downregulated $(p<0.01)$, whereas the Bax and Ccaspase-3 proteins were up-regulated $(p<0.01)$, compared with the normal group (Figure 3 ). After treatment with BSY, the down-regulated protein expression levels of Bcl-2, MMP, and VEGF were increased $(p<0.05, p<0.01$, and $p<0.01$, respectively) compared with the control rats. In addition, Bax and C-caspase-3 were decreased significantly by treatment with BSY at doses of 50,100 , and $200 \mathrm{mg} / \mathrm{kg}(p<0.01)$, compared with control rats.

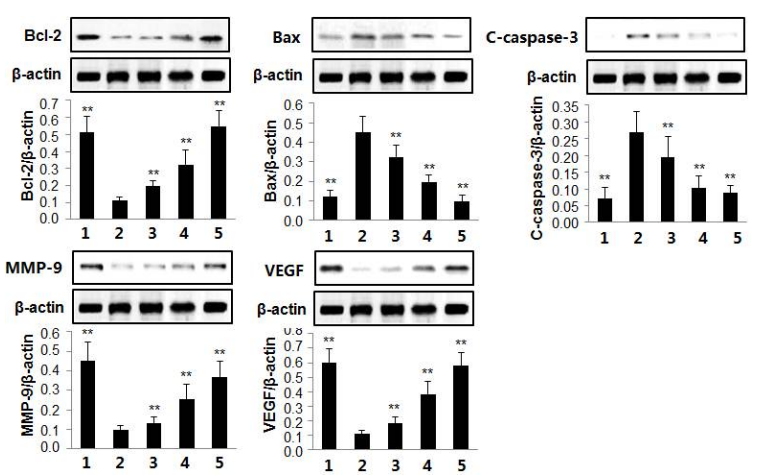

Figure 3: Effect of BSY on Bcl-2, Bax, C-caspase-3, MMP-9 and VEGF in ovarian tissue of anovulatory rats. Data are expressed as mean $\pm S D$, each group were consisted of 10 rats. All the drugs were treated orally; ${ }^{* *} p<0.01$, compared with control

\section{DISCUSSION}

BSY is one of the classical prescriptions for treating infertility in China, but in vivo animal experiments and chemical substance studies are still lacking. In the present study, the chemical constituents and pharmacological effects of BSY on androgen-sterilized anovulatory rats were determined. In addition, the possible pharmacological mechanisms of BSY were studied.
Previous reports have shown that natural extracts/compounds from plants are important resources for finding novel and effective drugs to treat various intractable diseases [16-18]. Flavones are reported to possess significant pharmacological activities including anti-sterility, anti-inflammatory, and anti-cancer activities $[19,20]$. HPLC assay is a very useful way for analysis the chemical composition of herbal medicines $[21,22]$. In the present study, by using HPLC assays with reference agents, seven constituents were identified from BSY, including rutin, tiliroside, quercetin, kaempferide, safflomin $A$, hyperoside, and quercitrin, suggesting that flavones might be active constituents of BSY.

The androgen-sterilized anovulatory rat is a classical experimental animal model used for investigating female fertility $[15,23]$. Normal follicular development is a pre-condition for ovulation and fertility. In recent years, studies have found that follicular development in the normal menstrual cycle is dependent on stimulation by gonadotropins such as FSH, LH, E2, P, and PRL [2,24]. FSH, LH, and E2 are necessary hormones for promoting follicular development and ovulation, whereas PRL is an inhibitory hormone [2]. In addition, $\mathrm{FSH}, \mathrm{LH}$, and E2 can also induce the aromatase activity of granulosa cells, leading to fission and proliferation of granular cells [2,25]. In the present investigation, the results suggested that BSY can significantly increase the levels of FSH, $\mathrm{LH}$, and E2, whereas it decreased PRL levels. It was reported that gonadotropin biosynthesis is mainly regulated by the INH-ACT-FS system, and that the INH-ACT-FS system functional disorders might result in failure of oocyte maturation $[25,26]$. INH, closely related to the growth of ovarian granular cells, can inhibit the biosynthesis and secretion of $\mathrm{FSH}$ in the pituitary $[15,27]$. ACT promotes FSH secretion, granulosa cell differentiation of ovarian follicles, and formation of cavity follicles [28]. In addition, FS, a binding protein for ACT and INH, restrained the aromatizing enzyme activity of granule cells and inhibited FSH biosynthesis [29]. The results indicated that treatment with BSY increased the 
levels of $\mathrm{FSH}, \mathrm{LH}$, and ACT, and decreased the levels of PRL, INH, and FS. These results further demonstrated that BSY extract improved follicle growth. In addition, the results also indicated that BSY promoted follicular development by regulating the INH-ACT-FS systems.

New development of the ovary is important to guarantee the nutrient and hormone supplies necessary to promote follicular development and corpus luteum formation. VEGF is one of the most important initiators of angiogenesis in ovarian development [9]. In addition, it is reported that matrix metalloproteinases (MMP) play essential roles in extracellular matrix remodelling in ovarian follicle growth and ovulation [8]. Granulosa cells also play very important roles in ovarian follicle growth and ovulation, and excess granulosa cell apoptosis could induce decreased ovarian reserve and follicular atresia [6]. The results of the present study showed that VEGF and MMP-9 were upregulated by treatment with $B S Y$. In addition, this study also indicated that treatment with BSY down-regulated pro-apoptosis proteins (caspase3 and $\mathrm{Bax}$ ) in ovarian tissues but up-regulated the anti-apoptosis protein (Bcl-2). These results indicate that BSY treatment is beneficial for follicle growth and ovulation via regulating VEGF, MMP-9, caspase-3, Bcl-2, and Bax in ovarian tissues.

\section{CONCLUSION}

BSY promotes follicular development by regulating the INH-ACT-FS system-related hormones, VEGF, MMP-9, Bcl-2, caspase-3, and Bax. However, the mechanism of action of BSY needs to be further investigated since the therapeutic effects of TCMs are the result of interactions of several pathways and targets. Collectively, the findings of this study suggest that BSY has potentials for use in the treatment of patients suffering from infertility.

\section{DECLARATIONS}

\section{Conflict of Interest}

No conflict of interest associated with this work.

\section{Contribution of Authors}

The authors declare that this work was done by the authors named in this article and all liabilities pertaining to claims relating to the content of this article will be borne by them.

\section{REFERENCES}

1. Practice Committee of American Society for Reproductive Medicine. Definitions of infertility and recurrent pregnancy loss: a committee opinion. Fertil Steril 2013; 99: 63.

2. Unuane $D$, Tournaye $H$, Velkeniers $B$, Poppe $K$. Endocrine disorders \& female infertility. Best Pract Res Clin Endocrinol Metab 2011; 25: 861-873.

3. Fu J, Yao R, Luo Y. Immune Infertility Should Be Positively Diagnosed Using an Accurate Method by Monitoring the Level of Anti-ACTL7a Antibody. Sci Rep 2016; 6: 22844.

4. Cao ZY. Obstetrics and gynecology. Beijing: People's Medical Publishing House 2008; 590.

5. Ma K. Present situation and question and prospect of study on kidney-supplementing and blood-activating method in treating ovaries functional disorders (infertility with dysfunctional ovulation) for stimulating ovaries reactive mechanism to gonadotropic hormones. Chin $\mathrm{J}$ Chin Mater Med 2011; 36: 2441-2444.

6. Rolaki A, Drakakis $P$, Millingos $S$. Novel trends in follicular development, atresia and corpus luteum regression: a role for apoptosis. Reprod Biomed Online 2005; 11: 93-103.

7. Parborell F, Irusta G, Tesone M. Angiopoietin 1 reduces rat follicular atresia mediated by apoptosis through the PI3K/Akt pathway. Mol Cell Endocrinol 2011; 343: 7987.

8. Bastos HB, Kretzmann N, Santos GO. Gene expression of matrix metalloproteinases and $\mathrm{LH}$ receptors in mare follicular development. Theriogenol 2014; 82: 11311136.

9. Pascuali N, Scotti L, Abramovich D. Inhibition of plateletderived growth factor (PDGF) receptor affects follicular development and ovarian proliferation, apoptosis and angiogenesis in prepubertal eCG-treated rats. Mol Cell Endocrinol 2015; 412: 148-158.

10. Jin XT, Ma K, Shan J. Clinical efficacy observation on therapy ovulation failure infertility caused by PCOS with reinforcing kidney, activating blood circulation and ovarian stimulation compound recipe. Chin J Chin Mater Med 2014; 39: 140-143.

11. Ried K. Chinese herbal medicine for female infertility: an updated meta-analysis. Complement Ther Med 2015; 23: 116-128.

12. Wang $X Y, L i Y Q$, Shang JW, Li L. TCM clinical diagnosis for male infertility. Jilin J Trad Chin Med 2014; 11: 10961098.

13. World Medical Organization. Declaration of Helsinki. Brit Med J 1996; 313(7070): 1448-1449.

14. Huang $W$, Zhang $Y$, Sun R. Comparative study on acute toxicity of different components of Polygonum multiflorum in mice. Chin J Pharmacovigilance 2010; 7: 705-707.

15. Malven PV, Francis R. Structural luteolysis of induced corpora lutea in "androgen-sterilized" rats. Anatomical Record 1969; 165: 55-60. 
16. Zhang $H Q$, Lu JJ, Zhang Y, Zhao YM, Wei J, Zhou LY. Anticonvulsant and sedative effect of Fufang Changniu pills and probable mechanism of action in mice. Trop $J$ Pharm Res 2016; 15: 1251-1257.

17. Wang $Q$, Kuang $H$, Su $Y$. Naturally derived antiinflammatory compounds from Chinese medicinal plants. J Ethnopharmacol 2013; 146: 9-39.

18. Zhou XB, Cao KW, Song LK, Kou SQ, Qu SC, Wang C, Yu Y, Liu Y, Li PY, Lu RP. Effect of acetone extract of Rumex japonicas Houtt on hydrogen peroxide-induced apoptosis in rat myocardial cells. Trop J Pharm Res 2017; 16: 135-140.

19. Jiang SJ, Xu L. Progress of pharmacological effects of total flavonoids from Epimedium brevicornu. Acta Chin Med Pharmacol 2004; 32: 60-62.

20. Singh P, Tomar R, Rath SK. Anticancer potential of the histone deacetylase inhibitor-like effects of flavones, a subclass of polyphenolic compounds: a review. Mol Biol Rep 2015; 42: 1515-1531.

21. Jiang YB, Lu XL, Peng W, Deng W, Ma YY. Study on the Influence of Sulfur Fumigation on Chemical Constituents of Angelicae dahuricae Radix (Baizhi). Trop J Pharm Res 2015; 14: 815-821.

22. Li Y, Lv XM, Tang C, Lai XR, Zhang Y, Fan G. Quality evaluation of cortex berberidis from different geographical origins by simultaneous high performance liquid chromatography combined with statistical methods. Trop J Pharm Res 2016; 15: 1973-1981.

23. Koh SB, Seo K, Kim SC, Ahn BO, Kim WB, Lee SH. Effect of recombinant human FSH on ovulation, pregnancy and in vitro fertilization in androgen-sterilized mice. Arch Pharm Res 2002; 25: 357-363.

24. Lan RX, Liu F, He ZB. Immunolocalization of GnRHRI, gonadotropin receptors, $P G R$, and PGRMCl during follicular development in the rabbit ovary. Theriogenol 2014; 81: 1139-1147.

25. Chen $Y$, He F, Wang ZY. How the activin-inhibin-follicle inhibition system affects the mouse oocytes in vitro maturation and the potential of early embryonic development. Reprod Contracep 2008; 28: 134-139.

26. Roberts VJ, Barth S, El-Roeiy A, Yen SS. Expression of inhibin/activin system messenger riso-nucleic acids and proteins in ovarian follicles women with polycystic ovarian syndrome. J Clin Endocrinol Metab 1994; 79: 1434-1439.

27. Pang $Y, G e$ W. Gonadotropin and activin enhance maturational competence of oocytes in the zebrafish (Danio rerio). Biol Reprod 2002; 66: 259-265.

28. Zhang ZP, Lv Y, Pan QJ. A study of Activin A promoting front of follicular cavity of mice. J Qingdao Agr Univ (Nat Sci Edit) 2011; 28: 5-8.

29. Dewailly D. Physiopathology of polycystic ovary syndrome. Ann Endocrinol 1999; 60: 123-130. 